\title{
Proceeding
}

Supplementary Issue: Summer Conferences of Sports Science. Costa Blanca Sports Science Events, 20-21 September 2019. Alicante, Spain.

\section{Myostatin and plasticity of skeletal muscle tissue}

\author{
VALENTINA PAGLIARA, ROSARITA NASSO, ANTONIO ASCIONE, MARIOROSARIO MASULLO, \\ ROSARIA ARCONE
}

Department of Sport and Well-being Sciences, Parthenope University, Naples, Italy

\begin{abstract}
Skeletal muscle is an extremely plastic tissue for its ability to respond to different stimuli such as physiological variation and external stress. Muscle hypertrophy involves an increase in muscle mass, changes in myofibril composition and adaptation of metabolic pathways. Plasticity of skeletal muscle in response to exercise training is also caused by proliferation and differentiation of the satellite muscle stem cells in response to various growth and differentiation factors. This process is mainly mediated by myokines secreted during skeletal muscle contraction. Myokines are proteins that act as hormones both locally in the muscle and/or in an endocrine manner in other organs, mainly liver, brain and adipose tissue. Myostatin, known as growth differentiation factor-8, a myokine member of transforming growth factor-b (TGF-b) superfamily, can act on muscle cells in an autocrine manner leading to inhibition of muscle myogenesis. Muscle myostatin expression and its plasma concentration are downregulated after acute and long-term physical exercise thus allowing muscle hypertrophy. In addition, myostatin is correlated to obesity and insulin resistance for its ability to affect energy metabolism and insulin-sensitivity in muscle cells, respectively. These findings reveal that myostatin may have potential therapeutic applications to treat muscle atrophy diseases in humans. Even in sports, drugs able to inhibit myostatin expression can lead athletes to increase their sport performance. Here, we present a brief overview of myostatin and its role in biological mechanisms involved in exercise-induced plasticity of skeletal muscle. Keywords: Myostatin; Skeletal muscle plasticity; Myokines; Physical activity.

\section{Cite this article as:}

Pagliara, V., Nasso, R., Ascione, A., Masullo, M., \& Arcone, R. (2019). Myostatin and plasticity of skeletal muscle tissue. Journal of Human Sport and Exercise, 14(5proc), S1931-S1937. doi:https://doi.org/10.14198/jhse.2019.14.Proc5.12

Corresponding author. Department of Sport and Well-being Sciences, Parthenope University, Naples, Italy.

E-mail: rosaria.arcone@uniparthenope.it

Supplementary Issue: Summer Conferences of Sports Science. Costa Blanca Sports Science Events, 20-21 September 2019. Alicante, Spain.

JOURNAL OF HUMAN SPORT \& EXERCISE ISSN 1988-5202

(c) Faculty of Education. University of Alicante

doi:10.14198/jhse.2019.14.Proc5.12
\end{abstract}




\section{INTRODUCTION}

The muscle plasticity is the ability of the muscle tissue to modify its structure, function and metabolism in response to contractile activity and many physiological changes (Hoppeler et al., 2011). This response includes the modification both in size and fibre composition of the skeletal muscle. Physical exercise plays a major role among factors affecting muscle plasticity, such as nutritional changes (Vogt et al., 2003), disuse (Bodine, 2013), hypoxia (Hoppeler et al., 2008), weightlessness (Desplanches, 1997). In particular, prolonged aerobic resistance exercises induce an increase of the number of mitochondria and associated proteins without any effect on fibre size (hyperplasia). On the contrary, a chronic increase in the workload affects the skeletal muscle leading to an increase in the cross section of the myofibril and concomitant variation in the type of contractile proteins (from type lla to type I) and in the activity of the enzymes involved in the tissue metabolism. On the contrary, the unloaded muscle undergoes atrophy. Several cellular and molecular mechanisms underlay these muscle modifications. There are also strictly biochemical aspects that regulate the miotrophism, such as insulin-like growth factors (IGF-1), hormones of a protein nature with a molecular structure similar to that of insulin. Produced mainly by the liver, IGF-1 promotes cell proliferation and differentiation, especially at the cartilage and muscle level by promoting the activity of satellite cells, through its muscle isoform, the mechanical growth factor (MGF). In addition, IGF-1 mediates many actions of growth hormone $(\mathrm{GH})$ and vice versa. $\mathrm{GH}$ activates muscle mass growth by stimulating the liver to release IGF-1 and especially MGF at the muscle level, the latter stimulating the transformation of satellite cells into myocytes. Levels of IGF-1 and MGF increase in plasma and skeletal muscle, respectively, after resistance exercises. On the contrary, as described below, myostatin plays a diametrically opposite role to the above growth factors. The aim of this work is to overview the role of myostatin in modulation of skeletal muscle plasticity induced by physical exercise.

\section{SKELETAL MUSCLE PLASTICITY}

Satellite cells are muscle stem cells that play a crucial role in muscle growth during hypertrophy and regeneration process (Tamura et al., 2017). Different growth factors and cellular events regulate the activation of muscle satellite cells during skeletal muscle regeneration that occurs following a myofibril damage, including the proliferation of satellite cells (Bazgir et al., 2017). Activated satellite cells are characterized by high expression of transcription factors such as MRF, MyoD and Myf5. The proliferative phase is followed by terminal differentiation and fusion of myoblasts with damaged myofibers to form the new myofibers that are similar to the original ones. During the process of muscle regeneration, some myoblasts return to the quiescent state to replenish the pool of satellite cells for subsequent muscle growth.

Growing evidences have demonstrated that contracting skeletal muscle releases soluble factors, termed myokines that affect the metabolic pathways of different tissues. Myokines can act either in autocrine or in para/endocrine manner on the adipose tissue, liver and brain through their receptors (Pedersen et al., 2007). Myokines that can act as positive and negative regulators such as various interleukins (IL-6, IL-7, IL-8 and IL-15), fibroblast growth factor 21 (FGF21), irisin, brain-derived neurotrophic factor (BDNF), insulin-like growth factor-1 (IGF-1), leukaemia inhibitory factor (LIF) and follistatin-like protein-1 (FSTL-1) and the small organic acid $\beta$-aminoisobutyric acid (BAIBA).

Up to now, secretome analysis of human myocyte culture medium has revealed over 100 myokines and only few of them have been extensively studied for their effects on skeletal muscle growth and metabolism, such IL-6, IL-15, BDNF, FGF21, irisin, myostatin, hepatocyte growth factor (HGF), insulin-like growth factor (IGF), leukaemia inhibition factor (LIF) and the family of transforming growth factor- $\beta$ (TGF- $\beta$ ) (Lee and Jun, 2019). 


\section{STRUCTURE AND FUNCTIONS OF MYOSTATIN}

Myostatin (MSTN), also termed growth and differentiation factor 8 (GDF-8) is a member of the TGF- $\beta$ superfamily that acts as negative regulator of skeletal muscle growth (McPherron and Lee, 1997). MSTN is predominantly expressed in the muscle tissues but it is also been detected in other tissues including the adipose tissue, mammary glands, heart, spleen, lymphocytes (Deng et al., 2017). Human MSTN is secreted as an inactive precursor protein (pro-myostatin, a disulphide-linked homodimer) that under-goes to a complex proteolytic processing to generate a disulphide-linked $\mathrm{C}$-terminal fragment dimer that is the biologically active molecule (Cotton et al., 2018). The mature myostatin consists of a heterotetramic complex with two active type II receptors (ActlIRA or ActllRB) and two type I receptors (ALK4), TGF- $\beta$ (ALK5) to initiate signalling (Lee and McPherron, 2018).

Several studies have reported that inactivating mutations in the MSTN gene can led to gross muscle hypertrophy in cattle (McPherron and Lee, 1997), mice (McPherron et al., 1997) and humans (Schuelke et al., 2004). In addition, the inactivation of the MSTN gene also caused a decrease of fat mass (Lin et al., 2002; McPherron and Lee, 2002). The molecular mechanisms by which myostatin acts as a negative regulator of muscle growth involves the inhibition of activation of satellite cells and myoblast proliferation, through the decrease of muscle protein synthesis. In addition, further evidences obtained using in vitro cell models demonstrated that myostatin may act as common regulator in the differentiation of both myogenic and adipogenic cells (Adornetto et al., 2013; Artaza et al., 2005; Konopka et al., 2018).

Myostatin activity is regulated mainly by follistatin that acts as an inhibitory factor (Negaresh et al., 2019). The expression of follistatin has been detected in almost all animal tissues and high level of this protein are correlated to a great muscle development (Hansen et al., 2011).

\section{EFFECT OF PHYSICAL EXERCISE ON MYOSTATIN EXPRESSION}

Physical exercise and sports training can induce myoblast differentiation from the quiescent stage to differentiated myotubes through activation of transcription factors involved in the myogenic process (Vitucci et al., 2018). It has been shown that physical exercise can modulate myostatin expression allowing muscle hypertrophy (Hallen et al., 2011; Drevon et al., 2016). However, several studies demonstrated that aerobic activity alone does not increase muscle mass and musculoskeletal strength that require resistant training.

Acute aerobic exercise combined with endurance and strength exercises down-regulate myostatin levels in skeletal muscle (Hittel et al., 2010) that is caused by the decrease of muscle expression (Louis et al., 2007). Resistance training can affect and/or prevent the age-related sarcopenia (Maltais et al., 2016) through a decrease in MSTN (Mero et al., 2013) that is associated to an increase of muscle protein synthesis and translational efficiency (Kumar et al., 2009).

On the contrary, diseases including obesity (Park et al., 2006; Hittel et al., 2010), reduced glucose tolerance and type 2 diabetes (Palsgaard et al., 2009) are associated with an up regulation of myostatin expression.

\section{MYOSTATIN IN THERAPEUTIC APPLICATIONS AND DOPING}

The progressive loss of the muscle mass that occurs during the aging process is termed sarcopenia and it share similarity pathological diseases including neuromuscular syndrome and cancer cachexia. In the light of myostatin functions, it has been immediately suggested that its inhibitors could be used either for the 
treatment of muscle-wasting conditions in human or in doping practices (Mazzeo and Raiola, 2018) to increase muscle growth.

In the medical field, research on myostatin is aimed at the treatment of diseases such as neuromuscular disease. The potential relevance of myostatin in the treatment of disease in humans has been suggested by studies involving mdx mice, which carry a mutation in the dystrophin gene and are therefore used as a genetic model for Duchenne and Becker muscle dystrophy. The treatment of these diseases involves the inhibition of myostatin.

In addition, also the use of neutralizing monoclonal antibodies directed against myostatin, can represent a useful to inhibit myostatin expression. Furthermore, the identification of components involved in the MSTN signalling pathway has allowed the development of pharmacological agents capable of blocking MSTN effects in vivo. These agents can inhibit myostatin acting at the transcriptional or protein biosynthesis level or impairing the receptor binding. Myostatin inhibitors have been divided into five different types: antimyostatin antibody, anti-ActRIIB antibody, anti-ActRIIB-Fc antibody, follistatin-AAV gene therapy and myostatin peptide. In terms of chemical structure, most of these inhibitors consist of peptides.

Recently, the compound IMB0901 has been reported to act as myostatin inhibitor (Dong, 2019; Liu et al., 2019) acting as an inhibitor of the promoter's activity, the signalling pathway and the regulation of positive myostatin feedback. In a cell model of atrophied myocardial cells, the compound IMB0901 was able to induce a negative modulation of myostatin effects impairing its transcription and signalling pathway. The important advantages of myostatin as a therapeutic target is its regulation of both protein degradation and protein synthesis. In summary, IMB0901 could be a double inhibitor of myostatin as it could simultaneously inhibit both the transcription activity and the signalling pathway, thus protecting muscle atrophy induced by cancerous cachexia through the inhibition of the ubiquitin-mediated proteolysis and protein synthesis promotion.

Therefore, IMB0901 as an attractive therapeutic option for the treatment of cancer-induced muscle atrophy. It also provides new research ideas for studying muscle atrophy induced by other chronic diseases. Even in sports, the availability of drugs capable of inhibiting myostatin action would lead many athletes to increase their performance quickly and with little training.

\section{CONCLUSIONS}

Myostatin can influence the plasticity of skeletal muscle and energy metabolism at multiple levels even more specifically through its relationship with physical exercise, glucose and lipid metabolism and with all the other factors that influence its expression.

Therefore, myostatin is a useful target to develop new strategies for treatment of diseases such as dystrophies and cancer, providing the possibility for the patient to preserve muscle mass. Finally, it will be equally important to take into account the aspects concerning doping substances and thus avoiding that myostatin inhibitors can be used improperly and to safeguard the health of athletes.

\section{AUTHORS' CONTRIBUTIONS}

The manuscript has been conceived by all the authors, and the specific contribution of which is to be referred to as follows: paragraphs n. 1 and 2 to Valentina Pagliara and Rosarita Nasso; n. 3 to Antonio Ascione; 
paragraphs n. 4 to Mariorosario Masullo and Rosaria Arcone. All the Authors participated to the Introduction and Conclusions paragraphs; Mariorosario Masullo and Rosaria Arcone wrote the manuscript.

\section{REFERENCES}

Adornetto A, Pagliara V, Renzo GD, Arcone R. (2013) Polychlorinated biphenyls impair dibutyryl cAMPinduced astrocytic differentiation in rat C6 glial cell line. FEBS Open Bio 3, 459-466. https://doi.org/10.1016/j.fob.2013.10.008

Allen DL, Hittel DS, McPherron AC. (2011) Expression and function of myostatin in obesity, diabetes and exercise adaptation. Med. Sci. Sports Exerc. 43, 1828-1835. https://doi.org/10.1249/mss.0b013e3182178bb4

Artaza JN, Bhasin S, Magee TR, Reisz-Porszasz S, Shen R, Groome NP, Meerasahib MF, GonzalezCadavid NF. (2005) Myostatin inhibits myogenesis and promotes adipogenesis in C3H 10T(1/2) mesenchymal multipotent cells. Endocrinology 146, 3547-3557. https://doi.org/10.1210/en.2005$\underline{0362}$

Bazgir B, Fathi R, Valojerdi MR, Mozdziak P, and Asgari A. (2017) Satellite Cells Contribution to Exercise Mediated Muscle Hypertrophy and Repair. Cell J. 18, 473-484.

Bodine SC. (2013) Disuse-induced muscle wasting. Int. J. Biochem. Cell Biol. 45, 2200-2208.

Cotton TR, Fischer G, Wang X, McCoy JC, Czepnik M, Thompson TB, Hyvönen M. (2018) Structure of the human myostatin precursor and determinants of growth factor latency. EMBO J. 37, 367-383. https://doi.org/10.15252/embj.201797883

Deng B, Zhang F, Wen J, Ye S, Wang L, Yang Y, Gong P, Jiang S. (2017) The function of myostatin in the regulation of fat mass in mammals. Nutr. Metab. (Lond) 14, 29. https://doi.org/10.1186/s12986017-0179-1

Desplanches D. (1997) Structural and functional adaptations of skeletal muscle to weightlessness. Int. J. Sports Med. 18 Suppl. 4, S259-S264. https://doi.org/10.1055/s-2007-972722

Dong L. (2019) IMB0901 inhibits muscle atrophy induced by cancer cachexia through MSTN signaling pathway. Skeletal Muscle, 9, 8. https://doi.org/10.1186/s13395-019-0193-2

Drevon CA and Norheim F. (2016) Myostatin in relation to physical activity and dysglycaemia and its effect on energy metabolism in human skeletal muscle cells. Acta Physiol. 217, 45-60. https://doi.org/10.1111/apha.12631

Hansen J, Brandt C, Nielsen AR, Hojman P, Whitham M, Febbraio MA, Pedersen BK, Plomgaard P. (2011) Exercise induces a marked increase in plasma follistatin: evidence that follistatin is a contraction-induced hepatokine. Endocrinology 152, 164-171. https://doi.org/10.1210/en.2010-0868

Hittel DS, Axelson M, Sarna N, Shearer J, Huffman KM, and Kraus WE. (2010) Myostatin decreases with aerobic exercise and associates with insulin resistance. Med. Sci. Sports Exerc. 42, 2023-2029. https://doi.org/10.1249/mss.0b013e3181e0b9a8

Hoppeler H, Klossner S, Vogt M. (2008) Training in hypoxia and its effects on skeletal muscle tissue. Scand. J. Med. Sci. Sports 18 Suppl. 1, 38-49. https://doi.org/10.1111/j.1600-0838.2008.00831.x

Hoppeler H, Baum O, Lurman G, Mueller M. (2011) Molecular mechanisms of muscle plasticity with exercise. Compr. Physiol. 1, 1383-1412. https://doi.org/10.1002/cphy.c100042

Konopka AR, Wolff CA, Suer MK, Harber MP. (2018) Relationship between intermuscular adipose tissue infiltration and myostatin before and after aerobic exercise training. Am. J. Physiol. Regul. Integr. Comp. Physiol. 315, R461-R468. https://doi.org/10.1152/ajpregu.00030.2018

Kumar V, Selby A, Rankin D, Patel R, Atherton P, Hildebrandt W, et al. (2009) Age-related differences in the dose-response relationship of muscle protein synthesis to resistance exercise in young and old men. J. Physiol. 587, 211-217. https://doi.org/10.1113/jphysiol.2008.164483 
Lee S, and McPherron AC. (2018) Structure of the human myostatin precursor and determinants of growth factor latency. EMBO J. 3, 367-383.

Lin J, Arnold HB, Della-Fera MA, Azain MJ, Hartzell DL, Baile CA. (2002) Myostatin knockout in mice increases myogenesis and decreases adipogenesis. Biochem. Biophys. Res. Commun. 291, 701706. https://doi.org/10.1006/bbrc.2002.6500

Liu D, Qiao X, Ge Z, Shang Y, Li Y, Wang W, Chen M, Si S, Chen SZ. (2019) IMB0901 inhibits muscle atrophy induced by cancer cachexia through MSTN signaling pathway. Skeletal Muscle 9, 8. https://doi.org/10.1186/s13395-019-0193-2

Lee JH, Jun HS. (2019) Role of Myokines in Regulating Skeletal Muscle Mass and Function. Front Physiol. 10, 42. https://doi.org/10.3389/fphys.2019.00042

Louis E, Raue U, Yang Y, Jemiolo B, and Trappe S. (2007) Time course of proteolytic, cytokine, and myostatin gene expression after acute exercise in human skeletal muscle. J. Appl. Physiol. 103, 1744-1751. https://doi.org/10.1152/japplphysiol.00679.2007

Maltais ML, Perreault K, Courchesne-Loyer A, Lagacé JC, Barsalani R, Dionne IJ. (2016) Effect of Resistance Training and Various Sources of Protein Supplementation on Body Fat Mass and Metabolic Profile in Sarcopenic Overweight Older Adult Men: A Pilot Study. Int. J. Sport. Nutr. Exerc. Metab. 26, 71-77. https://doi.org/10.1123/ijsnem.2015-0160

Mazzeo F, and Raiola G. (2018) An investigation of drugs abuse in sport performance. Journal of Human Sport and Exercise 13, S309-S319. https://doi.org/10.14198/jhse.2018.13.proc2.15

McPherron, AC and Lee SJ. (1997) Double muscling in cattle due to mutations in the myostatin gene. Proc. Natl. Acad. Sci. USA 94, 12457-12461. https://doi.org/10.1073/pnas.94.23.12457

McPherron AC, Lawler AM, Lee SJ. (1997) Regulation of skeletal muscle mass in mice by a new TGFbeta super-family member. Nature 387, 83-90. https://doi.org/10.1038/387083a0

McPherron AC, Lee SJ. (2002) Suppression of body fat accumulation in myostatin-deficient mice. J Clin. Invest. 109, 595-601. https://doi.org/10.1172/jci200213562

Mero AA, Hulmi JJ, Salmijärvi H, Katajavuori M, Haverinen M, Holviala J, et al. (2013) Resistance training induced increase in muscle fiber size in young and older men. Eur. J. App,I Physiol. 113, 641-650. https://doi.org/10.1007/s00421-012-2466-x

Negaresh R, Ranjbar R, Baker JS, Habibi A, Mokhtarzade M, Gharibvand MM, Fokin A. (2019) Skeletal Muscle Hypertrophy, Insulin-like Growth Factor 1, Myostatin and Follistatin in Healthy and Sarcopenic Elderly Men: The Effect of Whole-body Resistance Training. Int. J. Prev. Med. 5, 10-29. https://doi.org/10.21859/sija-120154

Palsgaard, J, Brons C., Friedrichsen M, Dominguez H, Jensen M, Storgaard H, Spohr C, Torp-Pedersen C, Borup R, De Meyts P, Vaag A. (2009) Gene expression in skeletal muscle biopsies from people with type 2 diabetes and relatives: differential regulation of insulin signalling pathways. PLoS ONE 4, e6575. https://doi.org/10.1371/journal.pone.0006575

Park JJ, Berggren JR, Hulver MW, Houmard JA, Hoffman EP (2006) GRB14, GPD1, and GDF8 as potential network collaborators in weight loss-induced improvements in insulin action in human skeletal muscle. Physiol. Genomic 114-121. https://doi.org/10.1152/physiolgenomics.00045.2006

Pedersen BK, Akerstrom TC, Nielsen AR and Fischer CP. (2007). Role of myokines in exercise and metabolism. J. Appl. Physiol. 103, 1093-1098. https://doi.org/10.1152/japplphysiol.00080.2007

Schuelke M, Wagner KR, Stolz LE, Hubner C, Riebel T, Komen W, Braun T, Tobin JF, Lee S. (2004) Myostatin mutation associated with gross muscle hypertrophy in a child. New Engl. J. Med. 50, 26822688. https://doi.org/10.1056/nejmoa040933 
Tamura K, Furuichi Y, Manabe Y, Fujii NL. (2017) Role of satellite cells in skeletal muscle plasticity: beyond muscle regeneration. J. Phys. Fitness Sports Med. 6, 89-93. https://doi.org/10.7600/jpfsm.6.89

Vitucci D, Imperlini E, Arcone R, Alfieri A, Canciello A, Russomando L, Martone D, Cola A, Labruna G, Orrù S, Tafuri D, Mancini A, Buono P. (2018) Serum from differently exercised subjects induces myogenic differentiation in LHCN-M2 human myoblasts. J. Sports Sci. 36, 1630-1639.

Vogt M, Puntschart A, Howald H, Mueller B, Mannhart C, Geeller- Tuescher L, Mullis P, Hoppeler H. (2003) Effects of dietary fat on muscle substrates, metabolism, and performance in athletes. Med. Sci. Sports Exerc. 35, 952-960. https://doi.org/10.1249/01.mss.0000069336.30649.bd 